\title{
PENGARUH PENDIDIKAN AGAMA ISLAM DALAM KELUARGA DAN BUDAYA RELIGIUS SEKOLAH TERHADAP KEDISIPLINAN BERAGAMA SISWA SMA ISLAM SINAR CENDEKIA TANGERANG SELATAN
}

\author{
MUHAMMAD ADLAN NAWAWI \\ Institut PTIQ Jakarta \\ adlan_nawawi@yahoo.com \\ RUDI ISKANDAR \\ Institut PTIQ Jakarta \\ rudiiskandar@yahoo.com
}

\begin{abstract}
ABSTRAK
Penelitian ini bertujuan untuk mengetahui dan menguji data-data empirik terkait pengaruh pendidikan agama islam dalam keluarga dan budaya religius sekolah terhadap kedisiplinan beragama siswa SMA islam sinar cendekia. penelitian ini, metode survey dengan pendekatan korelasional dan regresional terhadap data-data kuantitatif yang diperoleh dari objek penelitian yaitu siswa-siswa SMA Islam Sinar Cendekia Tangerang Selatan. Pengumpulan data dilakukan dengan menggunakan tekhnik angket/kuesioner, observasi, dan dokumentasi. Jenis analisis yang digunakan adalah analisis korelasi dan regresi yang djabarkan secara deskriptif. Hasil dari penelitian ini adalah Pertama, Hasil penelitian membuktikan bahwa terdapat pengaruh positif dan sangat signifikan antara pendidikan agama islam dalam keluarga terhadap kedisilina beragama dengan koefisien korelasi(r) sebesar 0,864 dan koefisien determinasi $\left(\mathrm{R}^{2}\right)=0,746$. Artinya pendidikan agama islam dalam keluarga dapat mempengaruhi kedisiplinan beragama sebesar 74,6\%. Sedangkan arah pengaruh ditunjukan dengan melalui persamaan regresi $\hat{Y}=$ $23,882+0,957 x^{1}$ artinya setiap peningkatan 1 unit skor pendidikan agama islam akan mempengaruhi peningkatan skor kedisiplinana beragama sebesar $=0,957$. Kedua, Hasil penelitian menunjukkan terdapat pengaruh positif dan signifikan budaya religius sekolah terhadap kedisiplinan beragama dengan koefisien korelasi (r) sebesar 0,919 dan koefisien determinasi $\left(R^{2}\right)$ sebesar 0,845. Artinya budaya religius sekolah dapat mempengaruhi kedisiplinan beragama sebesar 84,5\%. Sedangkan arah pengaruh ditunjukan dengan melalui persamaan regresi $\hat{Y}=$ $23,882+0,844 x^{2}$ artinya setiap peningkatan 1 unit skor budaya religius sekolah akan mempengaruhi peningkatan skor kedisiplinan beragama sebesar $=0,844$. Ketiga, Hasil penelitian menunjukkan terdapat pengaruh positif dan signifikan pendidikan agama islam dala keluarga dan budaya religius sekolah secara bersama-sama terhadap kedisiplinan beragama dengan koefisien korelasi (r) sebesar 0,935 dan
\end{abstract}


koefisien determinasi $\left(\mathrm{R}^{2}\right)$ sebesar $87,4 \%$. Arah pengaruh ditunjukan dengan melalui persamaan regresi ganda $\hat{Y}=17,835+0,281 x^{1}+0,603 x^{2}$ dan koefis-ien korelasi ganda ry.12 $=0,861$ dan koefisien determinasi sebesar ry. $1^{22}=0,884$.

Kata Kunci: Pendidikan Agama Islam, Budaya Religius, Kedisiplinan Beragama

\begin{abstract}
ABSTRAK
Cette recherche vise à connaître et à examiner les données empiriques liées à l'influence de l'éducation religieuse islamique dans la culture familiale et religieuse de l'école à la discipline religieuse des élèves islamiques du secondaire. Dans cette recherche, les auteurs utilisent une méthode d'enquête avec une approche corrélationnelle et regresional aux données quantitatives obtenues à partir de l'objet de recherche, qui est les étudiants de SMA Islam Sindekia South Tangerang. L'échantillon de cette étude était de 122 répondants sur un total de 174 répondants à l'érudit Sinar South Tangerang high school étudiants sur le semestre impair de l'année scolaire 2019-2020. La collecte de données se fait à l'aide de sondages/questionnaires, d'observations et de documentation. Le type d'analyse utilisé est une analyse de corrélation et de régression descriptive. Les résultats de cette étude sont les : First, the results proved that there was a positive and very significant influence between the education of Islamic religion in the family against the religious disilina with the correlation coefficient $(r)$ of 0.864 and coefficient of determination $(\mathrm{R} 2)=0.746$. This means that Islamic education in families can influence religious discipline by $74.6 \%$. While the direction of influence is demonstrated by through the equation of regression $\hat{Y}=23.882+0.957$ X1 means that any increase in 1 unit of Islamic Education score will affect the increase of religious discipline score of $=0.957$ point. Secondly, the results showed there was a positive and significant influence of school's religious culture towards religious discipline with a correlation coefficient (r) of 0.919 and coefficient of determination (R2) of 0.845 . This means that school's religious culture can affect religious discipline by $84.5 \%$. While the direction of influence is demonstrated by through the equation of regression $\hat{Y}=$ $23,882+0.844 \times 2$ means that each increase of 1 unit of religious cultural score of the school will affect the increase of religious discipline score of $=0.844$ point. Thirdly, the results show there is a positive and significant influence of Islamic education in the family and religious culture of the school together to the religious discipline with the correlation coefficient (r) of 0.935 and the coefficient Determinations (R2) of $87.4 \%$. The direction of influence is demonstrated by the double regression equation $\hat{Y}=$ $17.835+0.281 \mathrm{X} 1+0.603 \mathrm{X} 2$ and double correlation coefficient of ry. $12=0.861$ and coefficient of determination of ry. $122=0.884$ point.
\end{abstract}

Key words: Islamic religious Education, religious culture, religious discipline. 


\section{A. PENDAHULUAN}

Disiplin merupakan istilah yang sudah memasyarakat diberbagai instansi pemerintah maupun swasta. Kita mengenal adanya disiplin kerja, disiplin lalu lintas, disiplin belajar dan macam istilah disiplin yang lain. Disiplin secara etimologi berasal dari bahasa latin "disibel" yang berarti pengikut. Seiring dengan perkembangan bahasa, kata tersebut mengalami perubahan menjadi "disipline" yang artinya kepatuhan atau yang menyangkut tata tertib.

Disiplin merupakan wujud nyata dari penghargaan kita pada diri sendiri dan orang lain (Tim Penulis Grasindo). Disiplin adalah proses pelatihan pikiran dan karakter, yang meningkatkan kemampuan untuk mengendalikan diri sendiri dan menumbuhkan ketaatan atau kepatuhan terhadap tata tertib atau nilai tertentu. ${ }^{1}$

Pada hakekatnya, disiplin merupakan hal yang dapat dilatih. pelatihan disiplin diharapkan dapat menumbuhkan kendali diri, karakter atau keteraturan, dan efisiensi. Jadi secara singkat dapat disimpulkan bahwa disiplin berhubungan dengan pengendalian diri supaya dapat menbedakan mana hal yang benar dan mana hal yang salah sehingga dalam jangka panjang diharapkan bisa menumbuhkan perilaku yang bertanggung jawab dan kurang pengetahuan tentang peraturan, prosedur, dan kebijakan yang ada merupakan penyebab terbanyak tindakan indisipliner. Salah satu upaya untuk menghadapi tindakan tersebut, pihak pemimpin sebaiknya memberikan program orientasi kepada tenaga kerja mulai dari hari pertama masuk, kedisiplinan tidak akan berjalan dengan baik apabila kebijakan yang ada tidak diketahui dengan jelas aturanya. Pimpinan harus menjelaskan secara rinci peraturan - peraturan yang sering dilanggar berikut rasional dan konsekwensinya. Demikian pula peraturan/ prosedur atau kebijakan yang mengalami perubahan atau diperbaharui sebaiknya diinformasikan melalui diskusi.

Usaha yang dapat dilakukan oleh madrasah/sekolah dalam rangka penanaman disiplin terhadap siswa dengan mengkondisikan lingkungan madrasah sedemikian rupa sehingga menjadai kondusif dalam pembentukan disiplin bagi siswa. Terutama yang harus dikondisikan adalah prilaku dan sikap yang dicerminkan oleh guru, sehingga guru menjadi contoh dalam berdisiplin. Siswa tidak akan memiliki disiplin manakala melihat gurunya sendiri juga tidak disiplin. Guru harus menghindari ketidak sesuaian aturan dan tata tertib yang berlaku. Aturan yang bersifat kurikuler misalnya agenda yang telah dibuat dan direncanakan haruslah sesuai dengan jadual yang ditetapkan baik alokasi waktunya maupun dalam proporsinya.

Usaha yang dapat dilakukan oleh madrasah/sekolah dalam rangka penanaman disiplin terhadap siswa dengan mengkondisikan lingkungan madrasah sedemikian rupa sehingga menjadai kondusif dalam pembentukan disiplin bagi siswa. Terutama yang harus dikondisikan adalah prilaku dan sikap yang

Elvira Marcellia Devayanti, Makalah Kedisiplinan siswa disekolah, https://bagiilmunei.blogspot.com/2017/04/makalah-kedisiplinan-siswa-di-sekolah.html. Diakses pada 26 Agustus 2019 
dicerminkan oleh guru, sehingga guru menjadi contoh dalam berdisiplin. Siswa tidak akan memiliki disiplin manakala melihat gurunya sendiri juga tidak disiplin. Guru harus menghindari ketidak sesuaian aturan dan tata tertib yang berlaku. Aturan yang bersifat kurikuler misalnya agenda yang telah dibuat dan direncanakan haruslah sesuai dengan jadual yang ditetapkan baik alokasi waktunya maupun dalam proporsinya.

Adapun salah satu hal yang bisa dilakukan adalah dengan penciptaan budaya religius di sekolah. Penciptaan suasana atau budaya religius berarti menciptakan suasana atau iklim kehidupan keagamaan. Dalam konteks PAI di sekolah berarti penciptaan suasana atau iklim kehidupan keagamaan Islam yang dampaknya ialah berkem-bangnya suatu pandangan hidup yang bernapaskan atau dijiwai oleh ajaran dan nilai-nilai agama Islam, yang diwujudkan dalam sikap hidup serta keterampilan hidup oleh para warga sekolah. ${ }^{2}$

Dalam arti kata, penciptaan suasana religius ini dilakukan dengan cara pengamalan, ajakan (persuasif) dan pembiasaan-pembiasaan sikap yang agamis dengan cara baik secara vertical (habluminallah) maupun dengan horizontal (habluminannas) dalam lingkungan sekolah. Melalui penciptaan ini, peserta didik akan disuguhkan dengan keteladanan kepala sekolah dan para guru dalam mengamalkan nilai-nilai keimanan, dan salah satunya yang paling penting adalah menjadikan keteladanan itu sebagai dorongan untuk meniru dan mempraktikkannya baik di dalam sekolah atau di luar sekolah. Sikap peserta didik sedikit banyak pasti akan terpengaruh oleh lingkungan di sekitarnya. Dengan demikian, adanya budaya religious dan pendidikan agama Islam dalam keluarga dengan pengaruh keluarga lebih besar dari pengaruh guru ini menarik untuk diteliti lebih dalam kaitannya dengan pengaruhnya terhadap kedisiplinan beragama peserta didik.

\section{B. METODE}

Metode Penelitian dalam pengertian yang luas dapat diartikan sebagai cara ilmiah, untuk mendapatkan data dengan tujuan dan kegunaan tertentu. Sugiyono ${ }^{3}$ Metode penelitian adalah suatu proses ilmiah dalam rangka mendapatkan data dan informasi yang valid dengan tujuan untuk menemukan, mengembangkan dan membuktikan suatu hipotesis atau ilmu pengetahuan tertentu, sehingga dapat digunakan untuk memahami, memecahkan, dan mengantisipasi masalah dalam bidang tertentu.

Menilik uraian di atas, dan sesuai tingkat kealamiahan tempat penelitian, maka metode dalam penelitian ini mengunakan metode survai dengan pendekatan korelasional. Metode survai dipergunakan dengan pertimbangan-pertimbangan bahwa penelitian dilakukan untuk mendapat-kan data setiap variabel masalah

\footnotetext{
${ }^{2}$ Muhaimin, Pengembangan Kurikulum Pendidikan (Bandung: PT Remaja Rosdakarya,2005), 61.

${ }^{3}$ Sugiyono, Metode Penelitian Pendidikan Pendekatan Kuantitatif, Kualitatif, dan R \& D (Bandung Alfabeta tahun 2008), 3.
} 
penelitian dari tempat tertentu yang alamiah (bukan buatan) dengan alat pengumpul data berbentuk angket (kuesioner), test dan wawancara terstruktur dan berdasarkan pandangan

Pengambilan sempel dilakukan pada sebagian siswa, yakni kelas XI,XI,XII SMA Islam Sinar Cendekia swasta yang terakreditasi A (Sangat Baik), secara acak, sehingga jumlah siswa yang menjadi populasi adalah 122 orang dengan jumlah siswa sebagai populasi terjangkau sebanyak 174 orang. ${ }^{4}$

Jumlah anggota sampel sering dinyatakan dengan istilah ukuran sampel. Ukuran sampel yang diterima akan sangat bergantung pada jenis penelitiannya. Jika penelitiannya bersifat deskriptif, maka sampel minimunya adalah $10 \%$ dari populasi. Jika penelitianya korelasional, sampel minimunya adalah 30 subjek. Apabila penelitian kausal perbandingan, sampelnya sebanyak 30 subjek per group dan apabila penelitian eksperimental, sampel minimumnya adalah 15 subjek per group. ${ }^{5}$

Frankel dan Wallen ${ }^{6}$ menyarankan besar sampel minimum untuk penelitian deskriptif sebanyak 100, penelitian korelasional sebanyak 50, penelitian kausalkausal perbandingan sebanyak 30/group dan penelitian eksperimental sebanyak 30 atau15 per group. Sementara Slovin, ${ }^{7}$ menentukan ukuran sampel suatu populasi dengan formula:

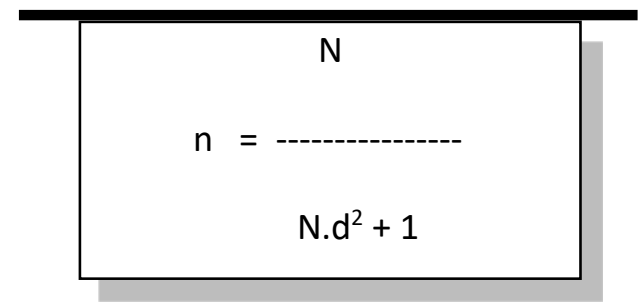

yaitu:

Keterangan:

$\mathrm{n}=$ ukuran sampel

$\mathrm{N}=$ ukuran populasi

$\mathrm{d}=$ nilai presisi 95\% atau tingkat kekeliruan 5\% (margin error, 0,05)

$1=$ konstanta

Pendapat lain tentang penentuan sampel ini dikemukakan Russeffendi ${ }^{8}$

${ }^{4}$ Sugiyono, Metode Penelitian Pendidikan Pendekatan Kuantitatif, Kualitatif, dan R \& D, 120.

${ }^{5}$ Gay, L.R. dan Diehl, P.L., Research Methods for Business and Management (New York: MacMillan Publishing Company, 1992), 102.

${ }^{6}$ Fraenkel, J. \& Wallen, N. How to Design and evaluate research in education. 2nd ed (New York: McGraw-Hill Inc. 1993), 92.

7 Parel, C.P. et.al. Sampling Design And Procedures (Philippines Social Science Council, 1994), 88.

${ }^{8}$ Russeffendi, E.T. Dasar-dasar Penelitian Pendidilkan dan Bidang Non Eksakta lainnya (Bandung, Tarsito, 1998), 30. 
yang menentukan sampel dengan ukuran pendekatan rata-rata populasi dengan rumus sebagai berikut:

yaitu:

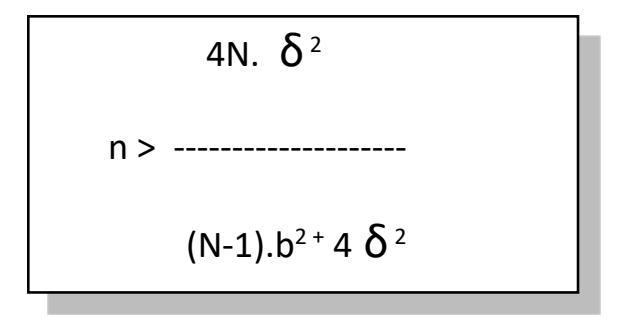

$\mathrm{n}=$ ukuran sampel

$\mathrm{N}=$ ukuran populasi

$\delta=$ simpang baku

$\mathrm{b}=$ batas kekeliruan estimasi error

Berdasarkan uraian di atas, maka dalam penelitian ini, peneliti menentukan ukuran sampel penelitian didasarkan pada pendapat Slovin. Dengan demikian, ukuran sampel yang berasal dari populasi terjangkau yaitu 174 orang siswa SMA Islam Sinar Cendekia swasta dari masing masing kelas XI,XII, XIII, maka dapat dihitung ukuran sampelnya adalah sebagai berikut:

$$
\begin{aligned}
& \begin{array}{lll}
174 & 174 & 174
\end{array} \\
& \mathrm{n}=\mathrm{-} 174(0,05)^{2}+1 \quad 174(0,0025)+1 \quad 2,0125 \\
& =121,25 \\
& \text { = } 122 \text { orang (dibulatkan) }
\end{aligned}
$$

Dengan demikian, jumlah sampel dalam penelitian ini adalah 122 orang, siswa SMA Islam Sinar Cendekia di Kota Tangerang Selatan.

Variabel penelitian dalam penelitian ini meliputi tiga variabel penelitian yaitu variabel terikat kedisiplinan beragama $(\mathrm{Y})$, variabel bebas pendidikan agama islam dalam keluarga $\left(X_{1}\right)$, variabel bebas $\left(X_{2}\right)$. Adapun skala pengukurannya menggunakan skala Likert dalam bentuk angket dengan lima alternatif jawaban,

Instrumen yang dipergunakan untuk mengumpulkan data dalam penelitian ini adalah berbentuk quesioner (angket) sebagai instrumen utama dan pedoman wawancara serta pedoman observasi sebagai instrumen pendukung.

Berdasarkan sumbernya, data dalam penelitian ini tergologong ke dalam jenis data data primer adalah data yang diperoleh atau dikumpulkan oleh peneliti secara langsung dari sumber datanya. Data primer disebut juga sebagai data asli atau data baru yang memiliki sifat up to date.

Penelitian ini tergolong jenis penelitian kuantitatif, oleh karena itu, maka sifat data dalam penelitian ini termasuk data interval yaitu data hasil pengukuran yang dapat diurutkan atas dasar kriteria tertentu yang diperoleh melalui kuesioner dengan skala Likert dengan alternatif jawaban yang diberi skor yang ekuivalen (setara) dengan skala interval, misalnya dengan skor. Adapun Sumber data terbagi menjadi dua yaitu data primer dan data sekunder. 
Berdasarkan uraian di atas, maka dalam penelitian ini sumber data primernya adalah siswa dan sumber data sekundernya adalah guru dan kepala sekolah pada SMA Islam Sinar Cendekia Swasta di Kota Tangerang Selatan. Selanjutnya, Teknik pengumpulan data dalam penelitian ini menggunakan teknik tidak langsung yaitu melalui quesioner atau angket untuk mendapatkan data yang bersifat pendapat atau persepsi. ${ }^{9}$

\section{HASIL DAN PEMBAHASAN}

Untuk membuktikannya, maka penelitian ini mengajukan tiga hipotesis yang pembuktiannya perlu diuji secara empirik. Ketiga hipotesis tersebut adalah merupakan dugaan sementara tentang pengaruh pendidikan agama islam dalam keluarga $\left(X_{1}\right)$ dan budaya religius sekolah $\left(X_{2}\right)$ baik secara sendiri-sendiri maupun secara bersama-sama terhadap kedisiplinan beragama $(Y)$. Oleh karena itu, di bawah ini secara lebih rinci masing-masing hipotesis akan diuji sebagai berikut:

1. Pengaruh pendidikan agama islam dalam keluarga $\left(X_{1}\right)$ terhadap kedisiplinan beragama $(\mathrm{Y})$

a. Adapun besarnya pengaruh ditunjukkan oleh koefisien determinasi $R^{2}(R$ square $=0,746$, yang berarti bahwa supervisi akademik kepala sekolah memberikan pengaruh terhadap kedisiplinan beragama sebesar 74,6\% dan sisanya yaitu 25,4\% ditentukan oleh faktor lainnya.

b. Arah pengaruh dapat dilihat dari hasil analisis regresi sederhana, menunjukkan persamaan regresi sederhana (unstandardized coefficients $B$ ) $\hat{Y}=$ $23,882+0,844 X_{1}$ yang berarti bahwa setiap peningkatan satu unit skor budaya religius sekolah akan mempengaruhi peningkatan skor kedisiplinan beragama sebesar 0,884. Adapun diagram pencar untuk persamaan regresi di atas adalah:

2. Pengaruh budaya religius sekolah $\left(\mathrm{X}_{2}\right)$ terhadap kedisiplinan beragama $(\mathrm{Y})$

Berdasarkan tabel 4.15 tentang pengujian hipotesis @y2 di atas, menunjukkan bahwa pada tingkat kepercayaan 95\% $(\alpha=0,05)$ diperoleh koefisien korelasi sederhana Pearson correlation ( $\varrho_{y 1}$ ) adalah 0,919 (korelasi sangat kuat) dan nilai signifikansi adalal 0,000<0,05 (korelasi signifikan). Dengan demikian, maka Ho ditolak dan Hi diterima, yang berarti bahwa terdapat pengaruh positif dan sangat kuat serta signifikan budaya religius terhadap kedisiplinan beragama. Adapun besarnya pengaruh ditunjukkan oleh koefisien determinasi $R^{2}$ ( $R$ square) $=0,845$, yang berarti bahwa budaya religius sekolah memberikan pengaruh terhadap kedisiplinan beragama sebesar 84,5\% dan sisanya yaitu 15,5\% ditentukan oleh faktor lainnya. Memperhatikan hasil analisis regresi sederhana, menunjukkan persamaan regresi sedehana (unstandardized coefficients $B$ ) $\hat{Y}=$ $23,882+0,844 \mathrm{X}_{2}$ yang berarti bahwa setiap peningkatan satu unit skor budaya

\footnotetext{
${ }^{9}$ Sugiyono, Metode Penelitian Pendidikan Pendekatan Kuantitatif, Kualitatif, dan R E D, 128-130.
} 
religius sekolah akan mempengaruhi peningkatan skor kedsiplinan beragama sebesar 0,844 .

3. Pengaruh pendidikan agama islam dalam keluarga $\left(\mathrm{X}_{1}\right)$ dan budaya religius sekolah $\left(\mathrm{X}_{2}\right)$ secara bersama-sama terhadap kedisiplinan beragama $(\mathrm{Y})$

Berdasarkan tabel 4.22 tentang pengujian hipotesis $R_{y .1 .2}$ di atas, menunjukkan bahwa pada tingkat kepercayaan $99 \%(\alpha=0,01)$ diperoleh koefisien korelasi ganda Pearson correlation ( $\mathrm{R}_{\mathrm{y} .1 .2}$ ) adalah 0,935 (korelasi sangat kuat) dan nilai signifikansi adalah $0,000<0,05$ (korelasi signifikan) Dengan demikian, maka Ho ditolak dan Hi diterima, yang berarti bahwa terdapat pengaruh positif dan sangat kuat serta signifikan pendidikan agama islam dalam keluarga dan budaya religius sekolah secara bersama-sama terhadap kedisiplinan beragama.

Adapun besarnya pengaruh ditunjukkan oleh koefisien determinasi $\mathrm{R}^{2}(R$ square $)=0,874$, yang berarti bahwa pengaruh pendidikan agama islam dalam keluarga dan budaya religius sekolah secara bersama-sama memberikan pengaruh terhadap kedisiplinan beragama sebesar $87,4 \%$ dan sisanya yaitu $6,2 \%$ ditentukan oleh faktor lainnya.

Memperhatikan hasil analisis regresi ganda, menunjukkan persamaan regresi (unstandardized coefficients $B$ ) $\hat{Y}=17,835+0,281 X_{1}+0,603 X_{2}$ yang berarti bahwa setiap peningkatan satu unit skor pendidikan agama islam dalam keluarga dan budaya religius sekolah secara bersama-sama, akan mempengaruhi peningkatan skor kedisiplinan beragama sebesar 0,884 .

Berdasarkan kedisiplinan beragama yaitu ketaatan seseorang dalam menjalani dan memeluk agama yang diyakininya, sehingga aturan agama yang ada baik itu hubungannya dengan orang lain dapat mencapai keteraturan dalam kehidupan sehari-hari. Melalui kedisiplinan beragama tersebut dapat melahirkan sebuah ketaatan agama yaitu menjalankan perintah-Nya dan menjauhi laranganNya baik hubungannya dengan Allah maupun dengan sesama manusia.

Hasil pengujian hipotesis pertama ini juga mendukung hasil penelitian sebelumnya yang berkaitan dengan masalah kedisiplinan beragama, seperti yang dilakukan oleh Luthfi Kholida Yonas, ${ }^{10}$ yang berjudul Pengaruh Pendidikan Agama Islam Dalam Keluarga dan Budaya Religius Sekolah Terhadap Kedisiplinan Beragama Peserta Didik MAN I Baureno, Bojonegoro. Hasil penelitiannya membuktikan bahwa 1) terdapat hubungan positif dan sangat signifikan antara pendidikan agama islam dalam keluarga terhadap kedisilina beragama, melalui persamaan regresi $\hat{Y}=23,882+0,957$ x1 dan koefisien korelasi ry.1 $=0,919$.

Kedua, hasil penelitian menunjukkan terdapat pengaruh positif dan signifikan budaya religius sekolah terhadap kedisiplinan beragama. Terdapat hubungan positif dan sangat signifikan antara motivasi kedisiplinan

${ }^{10}$ Luthfi Kholida Yonas, ${ }^{10}$ yang berjudul Pengaruh Pendidikan Agama Islam Dalam Keluarga dan Budaya Religius Sekolah Terhadap Kedisiplinan Beragama Peserta Didik MAN I Baureno, Bojonegoro, Tesis, Perpustakaan UIN Maulana Malik Ibrahim Malang Tahun 2016. 
beragama dengan budaya relligius sekolah, melalui persamaan regresi $\hat{Y}=23$, $882+0,844$ ×2 dan koefisien korelasi ry.2 $=0,919$.

Ketiga, hasil penelitian menunjukkan terdapat pengaruh positif dan signifikan pendidikan agama islam dala keluarga dan budaya religius sekolah secara bersama-sama terhadap kedisiplinan beragama.Terdapat hubungan positif dan sangat signifikan antara pendidikan agama islam dalam keluarga dan budaya religius sekolah terhadap kedisiplinan beragama melalui persamaan regresi ganda $\hat{Y}=17,835+0,281$ x1 $+0,603$ х2 dan koefisien korelasi ganda ry.12 $=0,861$ dan koefisien determinasi sebesar ry. $1^{22}=0,884$

\section{KESIMPULAN}

Berdasarkan hasil penelitian dan pembahasan sebagaimana telah dipaparkan diatas, maka hasil penelitian ini disimpulkan sebagai berikut :

1. Terdapat pengaruh yang signifikan secara bersama-sama antara Kedisiplinan Beragama siswa SMA Islam Sinar Cendekia. Yang berarti variabel Kedisiplinan Beragama Siswa berpengaruh terhadap pendidikan agama islam dalam keluarga, seperti terikat pada (py. $1=0,864$ dan $R$ square $=0,746$ yang artinya pendidikan agama islam memberikan pengaruh sebesar 74,6\%.

2. Terdapat pengaruh yang signifikan dari hasil angket siswa antara kedisiplinan beragama siswa SMA Islam Sinar Cendekia yang berarti variabel budaya religius sekolah berpengaruh terhadap kedisiplinan beragama, seperti terkait pada (py.2 =0,919 dan $\mathrm{R}$ square $=0,845$ yang artinya budaya religius sekolah memberikan pengaruh sebesar $84,5 \%$.

3. Terdapat pengaruh yang signifikan antara pendidikan agama islam dalam keluarga dan budaya religius sekolah terhadap kedisiplinan beragama siswa SMA Islam Sinar Cendekia. Yang berarti variabel pendidikan agama islam dalam keluarga dan budaya religius sekolah berpengaruh terhadap kedisiplinan beragama, seperti terikatpada $\left(\mathrm{R}_{\mathrm{y} .1 .2}\right)=0,935$ dan $\mathrm{R}$ square $=0,874$ sebesar $87,4 \%$.

Terdapat pengaruh yang signifikan secara bersama-sama antara pendidikan agama Islam dalam keluarga dan budaya religius sekolah terhadap kedisiplinan beragama siswa SMA Islam Sinar Cendekia. Persentase sumbangan pengaruh variabel independen (pendidikan agama Islam dalam keluarga dan budaya religius sekolah) terhadap variabel dependen (kedisiplinan beragama siswa).

Bahwasanya sekolah SMA Islam Sinar Cendekia harus meningkatkan pemahaman pendidikan agama islam dalam keluarga terhadap kedisiplinan beragama agar tercipta budaya religius dengan cara: Pertama, Upaya apa yang harus dilakukan dalam rangka kedisiplinan beragama melalui pendidikan agam islam dalam keluarga. Keberhasilan pendidikan agama akan memberikan kontribusi yang berarti bagi tercapainya tujuan pendidikan nasional. Pendidikan agama harus dilakukan secara integrasi dalam pendidikan nasional dan dilakukan terpadu di semua jalur baik formal, non formal maupun informal. Secara formal dan informal pendidikan agama maupun pendidikan keagamaan telah diatur melalui peraturan 
dan perundang-undangan yang sudah sangat memadai. Namun, untuk pendidikan agama secara informal tentu sangat bergantung kepada keluarga masing-masing, terutama orang tua.

Setiap orang tua tentu mengingin-kan anaknya menjadi orang yang berkembang secara sempurna. Mereka menginginkan anak yang dilahirkan kelak menjadi orang yang sehat, kuat, berketerampilan, cerdas, pandai dan beriman. Secara normatif, Islam telah memberikan peringatan bahwa kekhawatiran yang paling besar adalah ketika orang tua meninggalkan generasi sesudahnya dalam keadaan yang lemah. Tentu saja lemah dalam berbagai hal, terutama lemah iman, lemah ilmu serta tidak memiliki keterampilan hidup. Pengaruh pendidikan agama dalam keluarga terhadap kedisiplinan beragama sangat luas. Jika anak tidak mendapatkan pendidikan agama dari keluarganya sebagai pondasi hidup, maka kehidupannya tidak terkontrol. Tindakan amoral dan degradasi moral bangsa akan semakin meluas. Anak yang mendapatkan pendidikan agama dalam keluarga maka ia akan terbiasa melakukan perilaku keagamaan, sehingga terbentuk akhlak pada dirinya. Maka dari itu sekolah maupun orang tua bisa mengarahkan siswa nya maupun anaknya untuk dapat memahami pelajaran apa yang disampaikan sehingga siswa dapat mengaplikasikannya di sekolah maupun di lingkungan keluarga.

Kedua, Upaya apa yang dilakukan dalam rangka kedisiplinan beragama melalui budaya religius sekolah. Dari berbagai definisi tersebut, dapat diperoleh pengertian bahwa budaya religius sekolah adalah suatu sitem pengetahuan yang meliputi system ideal atau gagasan yang terdapat dalam pikiran manusia, sehingga dalam sehari-hari bersifat abstrak. Sedangkan perwujudannya ialah berupa perilaku, dan benda-benda yang bersifat nyata yakni, pola prilaku, bahasa, organisasi social, religi, seni, dan lain-lain. Yang kesemuanya ditunjuk untuk membantu siswa dalam melangsungkan kehidupan yang sesuai dengan contoh rosul yang diterapkan disekolahnya. Kebudayaan dapat tampak dalam bentuk perilaku siswa di sekolah yakni berupa hasil pemikiran yang direfleksikan dalam sikap dan tindakan.

Ciri yang menonjol antara lain adanya nilai-nilai yang dipersepsikan, dirasakan dan dilakukan. Hal tersebut dikuatkan dengan pendapat Tasmara yang menyatakan bahwa kandungan utama yang menjadi esensi budaya yaitu: a) Budaya berkaitan erat dengan persepsi terhadap nilai dan lingkungannya yang melahirkan makna dan pandangan hidup yang akan mempengaruhi sikap dan tingkah laku siswa disekolah; b) Adanya pola nilai, sikap, tingkah laku termasuk bahasa, hasil karsa dan karya, system kerja dan teknologi; c) Budaya merupakan hasil dari pengalaman hidup, kebiasaan-kebiasaan, serta proses seleksi norma-norma yang ada dalam cara dirinya berinteraksi social atau menempatkan dirinya ditengah-tengah lingkungan sekolah tertentu; d) Dalam proses budaya terdapat saling mempengaruhi dan saling ketergantungan baik social maupun lingkungan social.

Ketiga, Upaya apa yang harus dilakukan dalam rangka meningkatkan kedisiplinan beragama melalui pendidikan agama islam dalam keluarga dan budaya religius sekolah. Masa depan umat atau peradaban suatu bangsa sangat bergantung 
pada generasi yang disiapkan oleh generasi sebelumnya. Generasi suatu bangsa bergantung pada anak-anak yang disiapkan oleh keluarga, sedangkan penyiapan generasi yang terbaik harus melalui pendidikan. Pendidikan agama yang diberikan orang tua kepada anak dalam keluarganya, secara tidak langsung akan membentuk kedisiplin-an yang melekat pada diri anak. Sehingga, jika anak telah memiliki kedisiplinan beragama dan menjadi generasi yang baik. Maka yang harus dilakukan yaitu: a) Hubungan sekolah dan orang tua dalam mendidik harus selaras sehingga dapat tercipta keberhasilan dalam mendidik anak maupun siswa disekolah; b) Pelayanan sekolah harus lebih tersistematis dalam mendidik siswa-siswi disekolah dengan peraturan-peraturan maupun kebiasaan / budaya religius yang dicontohkan oleh warga sekolah sehingga tercipta kedisiplina beragama; c) Pemberdayaan SDM Sekolah dalam rangka penguatan keagamaan maupun wawasan kependidikan, dilaksanakan oleh sekolah maupun yayasan.

\section{DAFTAR PUSTAKA}

Elvira Marcellia Devayanti, Makalah Kedisiplinan siswa disekolah, https://bagiilmunei.blogspot.com/2017/04/makalah-kedisiplinan-siswa-di-sekolah.html. Diakses pada 26 Agustus 2019.

Fraenkel, J. \& Wallen, N. How to Design and evaluate research in education. 2nd ed. New York: McGrawHill Inc. 1993.

Gay, L.R.dan Diehl, P.L., Research Methods for Business and Management. New York: MacMillan Publishing Company, 1992.

Luthfi Kholida Yonas, ${ }^{1}$ yang berjudul Pengaruh Pendidikan Agama Islam Dalam Keluarga dan Budaya Religius Sekolah Terhadap Kedisiplinan Beragama Peserta Didik MAN I Baureno, Bojonegoro, Tesis, Perpustakaan UIN Maulana Malik Ibrahim Malang Tahun 2016.

Muhaimin, Pengembangan Kurikulum Pendidikan. Bandung: PT Remaja Rosdakarya, 2005.

Parel, C.P. et.al. Sampling Design And Procedures. Philippines Social Science Council, 1994.

Russeffendi, E.T. Dasar-dasar Penelitian Pendidilkan dan Bidang Non Eksakta lainnya. Bandung, Tarsito, 1998. Sugiyono, Metode Penelitian Pendidikan Pendekatan Kuantitatif, Kualitatif, dan $R$ \& $D$. Bandung Alfabeta, 2008. 